\title{
The in vitro Study of Streptomyces as Biocontrol Agent against the Ground nut Stem Rot Fungus, Sclerotium rolfsii (Sacc.)
}

\author{
K. Yamunarani ${ }^{1}$, A. Kalyanasundaram ${ }^{2 *}$ and M. Muthamizhan ${ }^{3}$ \\ ${ }^{1}$ Plant Pathology, ${ }^{2}$ Agricultural Entomology, Agricultural College and Research Institute \\ Eachangkottai, India \\ ${ }^{3}$ Department of Plant Pathology, Coimbatore, India \\ *Corresponding author
}

\section{A B S T R A C T}

\begin{tabular}{l} 
Key w or d s \\
$\begin{array}{l}\text { Sclerotium rolfsii, } \\
\text { Groundnut stemrot, } \\
\text { Streptomyces }\end{array}$ \\
\hline Article Info \\
$\begin{array}{l}\text { Accepted: } \\
\text { 15 October } 2020 \\
\text { Available Online: } \\
10 \text { November } 2020\end{array}$ \\
\hline
\end{tabular}

Native isolates of groundnut stem rot casual organism, Sclerotium rolfsii Sacc. were collected from major groundnut growing areas of Tamil Nadu. Selected isolates were screened, characterized and identified the virulent isolate. Morphology and spore structure of isolated antagonists, GNRAJK1 and GNRAVR14 were studied. The genus and species level of the antagonists was identified as Streptomyces violaceusniger and Streptomyces exfoliatus. The antagonistic activities of Streptomyces violaceusniger were found to be effective in reducing the mycelial growth, sclerotial formation and germination. The Streptomyces violaceusniger treated cultures were shown reduced mycelial growth $(85.00 \%)$ and reduced sclerotial production $(87.86 \%)$. The effect of crude antibiotics and volatiles of $S$. violaceusniger, $S$. exfoliates and $P$. fluorescens were studied against $S$. rolfsii, the results revealed the percent mycelial growth reduction of $S$. rolfsii over control by $S$. violaceusniger and $S$. exfoliatus were 69.56 and 66.17 per cent respectively. This study provides a theoritical and practical explanation of an antagonist explored for control of stem rot caused by Sclerotium rolfsii.

\section{Introduction}

Groundnut (Arachis hypogaea L.) is an important oilseed crop of India and it is called as the 'king' of oilseeds. Groundnut is cultivated in about 40.12 lakh ha in 2018-19 and production is 37.70 lakh tonnes and with an average yield $931 \mathrm{~kg} / \mathrm{ha}$ respectively. In spite of their important positions in national agricultural economy and the multiplicity of crops and crop growing situations, the countries out of oilseeds are lagging far behind the requirement. The groundnut production is constrained by various factors and the major constraints include as frequent drought stress, low input use and socio economic infrastructure and higher incidence of disease and pest attack.

Though the groundnut is attacked by number of diseases, the soil borne fungal disease, Aspergillus niger Van Tieghem, Sclerotium rolfsii Sacc and Rhizoctonia bataticola Taub have been reported to cause severe seedling 
mortality resulting patchy crop and reduced yield ranging from 25-40 per cent (Ghewande et al., 2002). Among soil borne pathogen Sclerotium rolfsii has wide host range, profile growth and ability to produce persistent sclerotia contribute the large economic losses.

The excessive use of chemical fungicides in agriculture has led to deteriorating human health, environmental pollution and development of pathogen resistance to fungicide. Microbial antagonists are widely used for the biocontrol of fungal plant diseases due to lack of induction of pathogen resistance and reduction of chemical fungicide residues in the environment. Understanding the pathogen, developing and relay on single antagonism become challengeable and give way to explore and identify the suitable alternate antagonist against the disease. Streptomyces are common inhabitants of rhizosphere and act as beneficial microorganisms for plant growth and development (Gopalakrishnan et al., 2013).

\section{Materials and Methods}

Effect of Streptomyces and Pseudomonas on mycelial growth and sclerotial Production of $S$. rolfsii under in vitro condition

The identified species of Streptomyces violaceusniger, Streptomyces exfoliates and Pseudomonas fluorescens bacteria were streaked in a four $\mathrm{cm}$ line $(1 \mathrm{~cm}$ away from the edge of the plate) on each PDA medium.

A nine mm mycelial disc of Sclerotium rolfsii was placed to the most distal point of the Petri dish perpendicular to the bacterial streak (Vidhyasekaran et al., 1997) and then plates were incubated at room temperature for four days and mycelial growths of the pathogen and sclerotial production were measured.
Efficacy of the culture filtrates of the antagonists against mycelial weight of $S$. rolfsii

Potato dextrose and King's B broths were prepared and distributed in $250 \mathrm{ml}$ conical flasks@100 ml per flask and sterilized at $1.04 \mathrm{~kg} / \mathrm{cm}^{2}$ pressure for 20 minute. The fungal and bacterial antagonists were inoculated into the sterilized potato dextrose and King's B broth and incubated for ten and two days respectively at room temperature $\left(28 \pm 2^{\circ} \mathrm{C}\right)$.

The cell free culture filtrates of the antagonistic organism were prepared by centrifugation of culture filtrates of the respective organism at $8000 \mathrm{rpm}$ for 20 minute. Then $10 \mathrm{ml}$ of the cell free culture filtrate of each of the antagonists were added to $90 \mathrm{ml}$ of potato dextrose broth (PDB) separately and sterilized in autoclave at 1.04 $\mathrm{kg} / \mathrm{cm}^{2}$ pressure for 20 minute. A nine $\mathrm{mm}$ disc of actively growing of $S$. rolfsii was inoculated into each flask under aseptic conditions and incubated at room temperature $\left(28 \pm 2^{\circ} \mathrm{C}\right)$ for one week. Then the mycelial mat of the pathogen were removed on pre weighed filter paper, air dried and weighed separately. Potato dextrose and King's B broths without any culture filtrates served as control. Three replications were maintained for each treatment. The results were expressed as mycelial dry weight of pathogen in gram.

\section{Antibiotics}

\section{Extraction of crude antimicrobial compounds from Streptomyces spp.}

The Streptomyces violaceusniger and Streptomyces exfoliates were grown in yeast extract malt extract medium at $28 \pm 2^{\circ} \mathrm{C}$ for seven days. Five $\mathrm{ml}$ of sterile distilled water was added to each sub cultured slants scrapped with a sterile needle and transferred 
to the inoculum medium. The inoculum was incubated on a rotary shaker for 4-5 days at $37^{\circ} \mathrm{C}$. After sufficient growth was obtained, the inoculum was incubated at $28^{\circ} \mathrm{C}$ for $72 \mathrm{~h}$. After the production period was over, the medium was centrifuged. The broth was separated. The mycelium was dried. The mycelial cake was extracted with methanol. The extracts were tested by poisoned food technique method against $S$. rolfsii. The separated broth samples were also tested for their anti microbial activity using poisoned food technique (Trejo- Estrada et al., 1998).

\section{Volatile compounds}

This study was performed by paired Petri dish technique (Laha et al., 1996). Two days old fresh cultures of $S$. violaceusniger and $S$. exfoliatus were uniformly streaked on yeast malt extract medium in a Petri dish. In another set, $9 \mathrm{~mm}$ diameter of mycelial disc cut from a four day old culture of $S$. rolfsii was placed at the centre of the PDA plate. Then the PDA plate with the pathogen (upper) was paired with the Petri dish containing the bacterial antagonist (lower) and sealed with parafilm. Dishes inoculated with $S$. rolfsii alone, paired with uninoculated yeast malt extract medium plate served as control. Three replications were maintained for each treatment. The paired plates were incubated at room temperature $\left(28 \pm 2^{\circ} \mathrm{C}\right)$ and colony diameter of $S$. rolfsii was measured at 5 days after incubation.

\section{Antibiotics}

\section{Extraction of crude antimicrobial compounds from antagonistic bacteria}

Cultures of $P$. fluorescens were grown at $28 \pm 2^{\circ} \mathrm{C}$ in Pigment Production medium (PPM) (Peptone-20g/l, Glycerol-20g/l, NaCl$5 \mathrm{~g} / \mathrm{l}, \mathrm{KNO}_{3}-1 \mathrm{~g} / \mathrm{l}, \mathrm{pH}-7.2$, Distilled Water1litre). The cultures were grown in PPM for five days and were centrifuged at $5000 \mathrm{rpm}$. The supernatants were adjusted to $\mathrm{pH} 2.0$ with conc. $\mathrm{HCl}$ and it was extracted with an equal volume of benzene. The Benzene layer was subjected to evaporation in water bath. After evaporation, the residues were resuspended in $0.1 \mathrm{~N} \mathrm{NaOH}$.

\section{Extraction and isolation of Phenazine}

Cultures of $P$. fluorescens were grown in nutrient broth at $30^{\circ} \mathrm{C}$ on a rotary shaker. The cells were collected by centrifugation at 3500 rpm for seven minutes. The pellets were suspended in pigment production broth and then incubated on a rotary shaker for four days at $30^{\circ} \mathrm{C}$. The antibiotic phenazine-1carboxylic acid (PCA) was isolated as per the procedure described by Rosales.

The antibiotic was separated in to respective fractions after acidifying the culture filtrate with $1 \mathrm{~N} \mathrm{HCl}$ to $\mathrm{pH} 2.0$ and then extracting the culture filtrate with an equal volume of Benzene (Phenazine). Then the benzene phase was extracted with 5 per cent $\mathrm{NaHCO}_{3}$. Phenazine-1-carboxylic acid was recovered from the bicarbonate layer while oxychlororaphine remained in the benzene layer. The bicarbonate fraction was extracted once again with benzene to recover phenazine from bicarbonate fraction. The antibiotic was air dried and dissolved in methanol.

Extraction of 2, 4- diacetylphloroglucinol (2, 4 -DAPG) (Rosales et al., 1995)

$P$. fluorescens were grown in $100 \mathrm{ml}$ of Pigment Production broth for four days on a rotary shaker at $30^{\circ} \mathrm{C}$. The fermentation broth was centrifuged at $3500 \mathrm{rpm}$ for five minute in a tabletop centrifuge and the supernatant was collected. It was acidified to $\mathrm{pH} 2.0$ with $1 \mathrm{~N} \mathrm{HCl}$ and then extracted with an equal volume of ethyl acetate. The ethyl acetate extracts were reduced to dryness in vacuo. The residues were dissolved in methanol. 
Effect of 2,4 - DAPG and Phenazine on the growth of $S$. rolfsii

The crude residues of Phenazine and 2, 4 DAPG were evaluated at $0.1 \%$ and $0.5 \%$ concentration for their inhibitory effect on the mycelial growth of $S$. rolfsii by poisoned food technique (Schmitz, 1930).

Effect of volatile compounds of the antagonistic bacterium

This study was performed following paired Petri dish technique. Two days old fresh cultures of $P$. fluorescens was uniformly streaked on King's B medium in a Petri dish. In another set $9 \mathrm{~mm}$ diameter of mycelial disc cut from a four day old culture of $S$. rolfsii was placed at the centre of the PDA plate. Then the PDA plate with the pathogen (upper) was paired with the Petri dish containing the bacterial antagonist (lower) and sealed with parafilm. Dishes inoculated with $S$. rolfsii alone, paired with uninoculated King's B medium plate served as control. Three replications were maintained for each treatment. The paired plates were incubated at room temperature and colony diameter of $S$. rolfsii was measured at 5 days after incubation (Laha et al., 1996).

\section{Results and Discussion}

Effect of Streptomyces and Pseudomonas on mycelial growth and sclerotial production of $S$. rolfsii under in vitro

Among the bacterial antagonists, the identified species $S$. violaceusniger was found to be highly effective in reducing the mycelial growth (86.45 per cent) than $S$. exfoliatus (83.06 per cent) and $P$. fluorescens (28.89 per cent). The sclerotial production was very less 37.00 numbers with highest reduction of 87.86 per cent over control in P. fluorescens treated plates. The $S$. violaceusniger and $S$. exfoliatus treated plates were shown 83.30 per cent and 79.66 per cent reduction of sclerotial production respectively.

\section{Effect of volatiles of bacterial antagonists on growth of $S$. rolfsii}

The volatile studies also revealed that the mycelial growth of S.rolfsii was reduced 69.56 per cent by $S$. violaceusniger and 66.17 per cent by S.exfoliatus with the mycelial diameter of $2.70 \mathrm{~cm}$ and $3.00 \mathrm{~cm}$ respectively. Similar observations were also made by earlier workers Geetha and Vikineswary (2002) who reported that S.violaceusniger G10 showed strong antagonism against F.oxysporum f.sp. cubense by producing extracellular antifungal metabolites. The volatiles of other bacterial antagonist $P$. fluorescens inhibited the mycelial growth by 54.57 per cent (Table 1).

The volatile studies of bacterial antagonists were conducted since the production of volatile cyanide is very common in rhizosphere Pseudomonas (Dowling and O'gara, 1994). Laha et al., (1996) stated that the volatile cyanogenic metabolites produced by $P$. fluorescens suppress the growth of $S$. rolfsii. Sharifi-ehrani and Omati (1999) observed a strong inhibitory effect on P.capsici by rhizosphere bacteria $P$. fluorescens and B. subtilis by production of volatiles. Volatile substances derived from Streptomyces $s p$. and other species of actinomycetes prevent mycelium growth and inhibit spore germination of different fungi (Kai et al., 2008). In another research, effects of volatile substances of S.globisporus were examined on spore germinating and mycelium growth Penicillium italicum and infected fruits. Among 41 volatile substances of this bacterium, Dimethyl disulfide and Dimethyl trisulfide have high inhibiting effects against fungus (Li et al., 2010). 
Table.1 Effect of volatiles of bacterial antagonists on growth of S. rolfsii

\begin{tabular}{|c|l|c|c|c|}
\hline $\begin{array}{c}\text { S.N } \\
\mathbf{0}\end{array}$ & \multicolumn{1}{|c|}{ Isolate } & $\begin{array}{c}* \text { Mycelial } \\
\text { diameter } \\
\text { (cm) }\end{array}$ & $\begin{array}{c}\text { Per cent } \\
\text { reduction over } \\
\text { control }\end{array}$ & Nature of growth of the pathogen \\
\hline $\mathbf{1}$ & P. fluorescens & 4.03 & 54.57 & Thin linear mycelial strands \\
\hline $\mathbf{2}$ & S. violaceusniger & 2.70 & 69.56 & Thin linear mycelial strands \\
\hline $\mathbf{3}$ & S. exfoliatus & 3.00 & 66.17 & Thin linear mycelial strands \\
\hline $\mathbf{4}$ & Control & 8.87 & - & Profused growth \\
\hline & CD (P=0.05) & $\mathbf{0 . 5 9}$ & & \\
\hline
\end{tabular}

* Mean of three replications

Table.2 Effect of crude antibiotics of Streptomyces sp. on S. rolfsii

\begin{tabular}{|c|c|c|c|c|c|}
\hline \multirow[t]{2}{*}{ S. No } & \multirow[t]{2}{*}{ Antibiotics } & \multicolumn{2}{|c|}{ Mycelial diameter (mm) } & \multicolumn{2}{|c|}{ Per cent reduction over control } \\
\hline & & $\begin{array}{c}\text { Concentration } \\
0.1 \%\end{array}$ & $\begin{array}{c}\text { Concentration } \\
0.5 \%\end{array}$ & $\begin{array}{c}\text { Concentration } \\
0.1 \%\end{array}$ & $\begin{array}{c}\text { Concentration } \\
0.5 \%\end{array}$ \\
\hline Brothextract & $\begin{array}{l}\text { Streptomyces } \\
\text { violaceusniger } \\
\text { Streptomyces exfoliates }\end{array}$ & $\begin{array}{l}27.66 \\
20.33\end{array}$ & $\begin{array}{l}14.40 \\
10.40\end{array}$ & $\begin{array}{l}69.20 \\
77.44\end{array}$ & $\begin{array}{l}\mathbf{8 4 . 0 0} \\
\mathbf{8 8 . 4 0}\end{array}$ \\
\hline $\begin{array}{l}\text { Methanolic } \\
\text { extract }\end{array}$ & $\begin{array}{l}\text { Streptomyces } \\
\text { violaceusniger } \\
\text { Streptomyces exfoliatus }\end{array}$ & $\begin{array}{l}23.00 \\
18.00\end{array}$ & $\begin{array}{l}11.33 \\
12.33\end{array}$ & $\begin{array}{l}74.40 \\
80.00\end{array}$ & $\begin{array}{l}87.40 \\
86.30\end{array}$ \\
\hline & Control & 90.00 & 90.00 & -- & -- \\
\hline $\begin{array}{l}\mathrm{CD}(\mathrm{P}=0 . \\
\text { Antibiotic } \\
\text { Concentra } \\
\text { A x C }\end{array}$ & $\begin{aligned} & =1.85 \\
=1.17 & \\
& =2.62\end{aligned}$ & & & & \\
\hline
\end{tabular}

Table.3 Effect of crude antibiotics of Pseudomonas fluorescens on S. rolfsii

\begin{tabular}{|c|c|c|c|c|c|}
\hline \multirow[t]{2}{*}{ S. No. } & \multirow[t]{2}{*}{ Antibiotics } & \multicolumn{2}{|c|}{ Mycelial diameter $(\mathrm{mm})$} & \multicolumn{2}{|c|}{ Per cent reduction over control } \\
\hline & & $\begin{array}{c}\text { Concentration } \\
0.5 \%\end{array}$ & $\begin{array}{c}\text { Concentration } \\
0.5 \%\end{array}$ & $\begin{array}{c}\text { Concentration } \\
0.1 \%\end{array}$ & $\begin{array}{c}\text { Concentration } \\
0.5 \%\end{array}$ \\
\hline 1 & Phenazine & 44.3 & 21.40 & 50.77 & 76.22 \\
\hline 2 & DAPG & 41.50 & 29.73 & 53.89 & 66.97 \\
\hline 3 & Control & 90.00 & 90.00 & -- & -- \\
\hline $\begin{array}{l}\mathrm{CD}(\mathrm{P}= \\
\text { Antibiot } \\
\text { Concent } \\
\text { A x C }\end{array}$ & $\begin{array}{l}05) \\
\text { s } \\
\text { tion }=1.60\end{array}$ & & & & \\
\hline
\end{tabular}

Effect of antibiotics of bacterial antagonists on mycelial growth of $S$. rolfsii

The crude antibiotic extracts from mycelium and broth were eluted from $S$. violaceusniger and $S$. exfoliatus to test its efficacy against $S$. rolfsii at 0.1 and 0.5 percent concentrations (Table 2). The maximum inhibition of 88.40 per cent was obtained in $S$. violaceusniger mycelial extract treatment at 0.5 per cent concentration and the extract from broth recorded 87.40 per cent mycelial growth 
reduction over control. The similar pattern of results were obtained by Trejo- Estrada et al., 1998, explained that, the biocontrol agent S.violaceusniger YCED9 inhibited in vitro growth of seven fungal pathogens of turf grass. Blasticidin-S and Kasugamycin. Blasticidin-S, isolated from $S$. griseochromogenes was the first antibiotic commercially introduced for the control of rice blast in Japan. Three different antibiotics were produced by the S.violaceusniger YCED9 including nigericin, geldanamycin and guanidylfunginA and a complex of macrocyclic lactone antibiotics, but only nigericin was detected in soil. The other studies also supports that, the another species S. hygroscopius inhibit broad range of fungal pathogens (El-Abyad et al., 1993; Rothrock and Gottlieb, 1984) (Table 3).

Several metabolites with antibiotic nature produced by pseudomonads have been studied and characterized so far, e.g., the cyclic lipopeptide amphysin, 2,4diacetylphloroglucinol (DAPG), oomycin A, the aromatic polyketidepyoluteorin, pyrrolnitrin, the antibacterial compound tropolone (De Souza et al., 2003). More recently, Siddique et al., 2013 reported that avermectin B1b, a component of commercially available abamectin, was obtained as a fermentation product of Streptomyces avermitilis

Present study investigated unexplored microorganisms and isolated location specific biocontrol agents for the management of stem rot of ground nut caused by Sclerotium rolfsii as an alternate for existing biocontrol agents.

\section{References}

De Souza J.T., de Boer M., de Waard P., van Beek T.A., Raaijmakers J.M. Biochemical, genetic, and zoosporicidal properties of cyclic lipopeptide surfactants produced by Pseudomonas fluorescens. 2003. Appl. Environ. Microbiol.; 69:7161-7172.

Dey R, Pal KK, Bhatt DM, Chauhan SM (2004) Growth promotion and yield enhancement of peanut (Arachis hypogaea L.) by application of plant growth-promoting rhizobacteria. Microbiol Res 159:371-394

Dowling, D.N and F. O'Gara. 1994. Metabolites of Pseudomonas involved in the biocontrol of plant disease. TIBTECH, 12: 133-141.

El-Abyad, M.S., M. A. El-Sayad., A. R. ElShanshoury and S.M. El-Sabbagh. 1993. Towards the biological control of fungal and bacterial diseases of tomato using antagonistic Streptomyces spp. Plant Soil. 149: 185-95.

Getha, K. and S. Vikineswary. 2002. Antagonistic effects of Streptomyces violaceusniger strain G10 on Fusarium oxysporum f. sp. cubenserace 4: Indirect evidence for the role of antibiosis in the antagonistic process. J. Ind. Microbiol. Biotechnol., 28: 30310.

Ghewande, M.P., Desai, S., and Basu, M.S., 2002, Diagnosis and management of major diseases of groundnut. NRCG Bull. 1:8-9

Gopalakrishnan S, Srinivas V, Vidya, Rathore A (2013) Plant growthpromoting activities of Streptomyces spp. in sorghum and rice. Springer Plus 2:574

Jodi Woan-FeiLaw et al., 2017. The Potential of Streptomyces as Biocontrol Agents against the Rice Blast Fungus, Magnaporthe oryzae (Pyricularia oryzae). Front Microbiol.; 8: 3.

Kai M, Vespermann A, Piechulla B. 2008.Plant Signal Behav. 3:482-484.

Laha, G.S., J.P. Verma and R.P. Singh. 1996. Effectiveness of fluorescent pseudomonads in the management of sclerotial wilt of cotton. Indian 
Phytopathol., 49 (1): 3-8.

Li Q, Ning P, Zheng L, Huang J, Li G, Hsiang T. 2010. Postharvest Biol Technol. 58:157-165.

Rosales, A.M., Mew, T.W., 1997. Suppression of Fusarium moniliforme in rice by rice-associated antagonistic bacteria. Plant Dis. 81: 49-52.

Rothrock, C.S. and D. Gottlieb. 1984. Role of antibiosis in antagonism of $S$. hygroscopicus var. geldanus to Rhizoctonia solani in soil. Can. J. Microbiol., 30: 1440-7.

Schmitz, H. 1930. Poisoned food technique Industrial and Engineering Chemistry. Analyst, 2: 361.

Sharifi Tehrani, A. and F.Omati. 1999. Biological control of Phytophthora capsici, the casual agent of pepper damping off by antagonistic bacteria medelelingen Faculteit Land bouw
Kundige in Toege Paste Biologische Wetens chappen, Universit cit Gent.,36: 419-423.

Siddique S., Syed Q., Adnan A., Nadeem M., Irfan M., Qureshi F.A. Production of avermectin B1b from Streptomyces avermitilis 41445 by batch submerged fermentation. Jundishapur. 2013.J. Microbiol. 6: 7198.

Trejo-Estrada, S.R., A. Paszczynski and D.L. Crawford. 1998. Antibiotics and enzymes produced by the biocontrol agent Streptomyces violaceusniger YCED9. J Ind Microbiol Biotechnol., 21: 81-90.

Vidhysekaran, P. 1997. Fungal pathogenesis in plants and crops: Molecular biology and host defence mechanisms. Marcel Dekkar, New York, 553 p.

\section{How to cite this article:}

Yamunarani, K., A. Kalyanasundaram and Muthamizhan, M. 2020. The invitro Study of Streptomyces as Biocontrol Agent against the Ground nut Stem Rot Fungus, Sclerotium rolfsii (Sacc.). Int.J.Curr.Microbiol.App.Sci. 9(11): 2013-2019.

doi: https://doi.org/10.20546/ijcmas.2020.911.239 